Jurnal Qua Teknika, Vol. 7 No. 2 September 2017

ISSN 2088 2424(cetak); 2527 3892(elektronik)

UNISBA Blitar, Http:// qua.unisbablitar.ejournal.web.id

Imam Muklisin, Ahmad Sholehuddin, Muklison. 2017. Pendeteksi Volume Tandon Air Secara Otomatis

Menggunakan Sensor Ultrasonic Berbasis Arduino Uno R3. Jurnal Qua Teknika, (2017), 7(2):55 65.

\title{
PENDETEKSI VOLUME TANDON AIR SECARA OTOMATIS MENGGUNAKAN SENSOR ULTRASONIC BERBASIS ARDUINO UNO R3
}

\author{
Imam Muklisin, Ahmad Sholehuddin, Muklison \\ Fakultas Teknik, Universtas Islam Balitar \\ email: ihlasimam@gmail.com
}

\begin{abstract}
Abstrak
Kemajuan ilmu pengetahuan dan teknologi berperan mewujudkan kehidupan yang lebih baik. Berbagai macam peralatan dengan sistem pengoperasian secara manual semakin ditinggalkan beralih pada peralatan yang serba otomatis, sehingga peralatan otomatis lebih mendominasi dalam kehidupan manusia. Perencanaan dan Pembuatan Pendeteksi Volume Tandon Air Secara Otomatis Menggunakan Sensor Ultrasonic Berbasis Arduino Uno R3 didesain dengan operasional yang sederhana sehingga mudah pengoperasiannya. Alat ini berfungsi untuk mengontrol volume pada bak penampung air sekaligus menghidupkan atau mematikan mesin pompa air secara otomatis. Sistem pendeteksi volume tandon air ini menggunakan sensor ultrasonic SRF HRC04. Mikrokontroler arduino uno R3 digunakan sebagai sistem control sinyal masukan dan keluar serta LCD $16 x 2$ sebagai penampilan datanya. Pengujian dilakukan dengan memberikan variasi jarak sensor terhadap muka air dari $2 \mathrm{~cm}$ sampai $18 \mathrm{~cm}$. system yang telah dibuat dilakukan kalibrasi agar layak digunakan sebagai alat ukur ketinggian air. Berdasarkan hasil penelitian dapat disimpulkan bahwa sistem pendeteksi volume tandon air dapat bekerja dengan baik sesuai dengan yang diharapkan yaitu dapat mengontrol volume ketinggian air pada tandon penampungan secara otomatis dengan ketepatan 99,10\% dan kesalahan 0,90\%.
\end{abstract}

\section{Kata kunci: Pompa Otomatis, Sensor Ultrasonic, Arduino, Relay}

\section{PENDAHULUAN}

Pada umumnya pengisian air pada bak penampungan air dengan menggunakan mesin pompa air, di mana pompa air berfungsi untuk menghisap air untuk dimasukan kedalam bak penampungan air atau tedmond. Tedmond biasanya dipakai oleh pengelola air bersih, penampungan air yang besar, kebutuhan rumah tangga sehari-hari, khususnya yang menggunakan mesin pompa air dari dalam sumur dan Perusahaan Daerah Air Minum (PDAM).

Sistem kerja pengisian air ini masih membutuhkan pengawasan penuh. Pompa air harus dihidupkan bila bak penampungan air kosong dan juga sebaliknya pompa harus dimatikan bila bak penampungan air sudah penuh. Hal ini cukup merepotkan karena bila lupa mematikan pompa air, maka air yang ada di dalam bak penampungan terlalu penuh hingga meluap dan ini akan mendapatkan kerugian. Pengelolaan air pada bak penampungan air sudah dikembangkan sebelumnya dengan sistem kontrol berupa katup dan pelampung. Sistem kerjanya sederhana, keran air manual yang biasanya untuk menutup dan membuka kembali aliran air dengan cara diputar, sedangkan keran pelampung menutup dan membuka bekerja secara otomatis. Katup berfungsi untuk menutup dan membuka aliran air ke dalam bak penampungan yang dikontrol oleh pelampung bahwa pelampung dikontrol oleh tingkat ketingian dan kerendahan air. Pelampung berfungsi untuk memberi batasan kapan katup akan membuka dan menutup aliran air pada posisi tertentu sesuai dengan panjang besi pelampung. Biasanya panjangnya berkisar $10 \mathrm{~cm}$ sampaidengan $30 \mathrm{~cm}$. Sistem kontrol ini juga sudah dikembangkan agar dapat mematikan dan menghidupkan pompa air secara otomatis dengan 
Jurnal Qua Teknika, Vol. 7 No. 2 September 2017

ISSN 2088 2424(cetak); 2527 3892(elektronik)

UNISBA Blitar, Http:// qua.unisbablitar.ejournal.web.id

Imam Muklisin, Ahmad Sholehuddin, Muklison. 2017. Pendeteksi Volume Tandon Air Secara Otomatis

Menggunakan Sensor Ultrasonic Berbasis Arduino Uno R3. Jurnal Qua Teknika, (2017), 7(2):55 65.

mengunakan switch. Kontrolutamanya memanfaatkan sistem kerja pelampung, saklar dipasang diposisi paling atas dan bila pelampung diangkat oleh air sampai ketinggian yang telah ditentukan dan menyentuh swicth maka dengan sendirinya pompa akan mati secara otomatis.

Namun sistem kontrol ini memiliki kelemahan di antaranya pompa akan hidup lebih dari 1 kali dalam sehari karena air yang ada di dalam bak penampungan belum sampai setengah, pompa sudah hidup kembali dan seterusnya bisa dibayangkan betapa melonjaknya pemakaian listrik, tidak ada tanda bila air sudah penuh, kerusakan pada pelampung sering terjadi karena pelampung kemasukan air. Untuk mengatur operasi pompa secara otomatis sesuai dengan kebutuhan kita diperlukan alat pengontrol kerja pompa. Sistem kontrol ini juga sudah dikembangkan, pada umumnya ada dua jenis alat kontrol yang banyak dipakai melengkapi pompa air rumah tangga, yaitu pressure switch (bekerja berdasarkan tekanan air di sisi keluaran pompa) dan Volume control (berdasarkan ketinggian permukaan air yang berada di dalam bak penampungan). Prinsip kerja kedua alat ini sama yaitu tombol (pemutus dan penghubung arus listrik). Bedanya gaya untuk membuka tuas penghubung arusnya adalah gaya berat pelampung untuk Volume control, sedang untuk pressure switch adalah gaya akibat tekanan air di sisi keluaran pompa, namun akibatnya terhadap operasi pompa berbeda. Bila menggunakan Volume control, pompa akan mati bila kedua pelampung mengambang di permukaan Volume air dan hidup lagi manakala kedua pelampung tergantung, artinya muka air berada di bawah kedua pelampung yang tergantung pada switch. Jadi hidup matinya pompa (start-stop) cukup lama. Sedangkan pressure switch mengakibatkan start stop lebih sering karena begitu tekanan sisi keluar pompa turun akibat keran terbuka, maka pompa akan start dan akan mati sesaat setelah semua aliran keluar pompa tertutup. Konsekuensinya umur pressure switch biasanya lebih pendek (lebih cepat rusak).

Melihat dari latar belakang itu, maka diberikan solusi dengan Perencanaan dan Pembuatan alat untuk tugas akhir dengan judul, "Perencanaan dan Pembuatan Pendeteksi Volume Tandon Air Secara Otomatis Menggunakan Sensor Ultrasonic Berbasis Arduino Uno R3". Untuk mengukur Volume ketinggian air pada tedmond / bak penampungan air, maka dibutuhkan sebuah sensor yang mampu membaca atau mengukur dengan akurat berapa ketinggian air pada tedmond. Kemudian bagaimana cara mengolah data sensor sebagai input dari Arduino Uno R3 untuk mematikan dan menghidupkan pompa air secara otomatis tanpa harus dilakukan secara manual.

Adapun tujuan penulisan tugas akhir ini sebagai berikut : 1) Membuat pendeteksi Volume air berbasis Arduino Uno R3 pada Tandon air menggunakan sensor Ultrasonic. 2) Menerapkan pendeteksi Volume air berbasis Arduino Uno R3 pada bak penampungan air menggunakan sensor Ultrasonic.

\section{KAJIAN LITERATUR}

\section{Uno Arduino R3}

Uno Arduino adalah board berbasis mikrokontroler pada ATmega328. Board ini memiliki 14 digital input / output pin, dimana 6 pin dapat digunakan sebagai output PWM (Pulse Width Modulator), 6 input analog, $16 \mathrm{MHz}$ osilator kristal, koneksi USB, jack listrik tombol reset. Pin-pin ini berisi semua yang diperlukan untuk mendukung mikrokontroler, hanya terhubung ke komputer dengan kabel USB atau sumber tegangan bisa didapat dari adaptor AC-DC atau baterai untuk menggunakannya.

\section{Catu Daya}

Uno Arduino dapat diaktifkan melalui koneksi USB atau dengan catu daya eksternal. Sumber listrik dipilih secara otomatis. Eksternal (non-USB ) daya dapat datang baik dari AC- 
Jurnal Qua Teknika, Vol. 7 No. 2 September 2017

ISSN 2088 2424(cetak); 2527 3892(elektronik)

UNISBA Blitar, Http:// qua.unisbablitar.ejournal.web.id

Imam Muklisin, Ahmad Sholehuddin, Muklison. 2017. Pendeteksi Volume Tandon Air Secara Otomatis

Menggunakan Sensor Ultrasonic Berbasis Arduino Uno R3. Jurnal Qua Teknika, (2017), 7(2):55 65.

DC adaptor atau baterai. Adaptor ini dapat dihubungkan dengan cara menghubungkannya plug pusat-positif $2.1 \mathrm{~mm}$ ke dalam board colokan listrik. Lead dari baterai dapat dimasukkan ke dalam header pin Gnd dan Vin dari konektor Power.

Board dapat beroperasi pada pasokan daya dari 6 - 20 volt. Jika diberikan dengan kurang dari $7 \mathrm{~V}$, bagaimanapun, pin $5 \mathrm{~V}$ dapat menyuplai kurang dari 5 volt dan board mungkin tidak stabil. Jika menggunakan lebih dari $12 \mathrm{~V}$, regulator tegangan bisa panas dan merusak board. Rentang yang dianjurkan adalah 7 - 12 volt.

\section{Input \& Output}

Masing-masing dari 14 pin digital pada Uno dapat digunakan sebagai input atau output, menggunakan fungsi pin Mode(), digital Write(), dan digital Read(). Mereka beroperasi di 5 volt. Setiap pin dapat memberikan atau menerima maksimum $40 \mathrm{~mA}$ dan memiliki resistor pull-up internal dari $20-50 \mathrm{~K} \Omega$.

\section{Komunikasi}

Uno Arduino memiliki sejumlah fasilitas untuk berkomunikasi dengan komputer, Arduino lain, atau mikrokontroler lain. ATmega 328 ini menyediakan UART TTL (5V) komunikasi serial, yang tersedia pada pin digital 0 (RX) dan 1 (TX). Sebuah ATmega16U2 pada saluran board ini komunikasi serial melalui USB dan muncul sebagai com port virtual untuk perangkat lunak pada komputer. Firmware Arduino menggunakan USB driver standar COM, dan tidak ada driver eksternal yang dibutuhkan. Namun pada Windows file ini diperlukan.

Perangkat lunak Arduino termasuk monitor serial yang memungkinkan data sederhana yang akan dikirim ke board Arduino. RX dan TX LED di board akan berkedip ketika data sedang dikirim melalui chip USB-to-serial dan koneksi USB ke komputer. ATmega 328 ini juga mendukung komunikasi I2C (TWI) dan SPI. Fungsi ini digunakan untuk melakukan komunikasi inteface pada sistem.

\section{Programming}

Uno Arduino dapat diprogram dengan perangkat lunak Arduino. Pilih Arduino Uno dari Tool lalu sesuaikan dengan mikrokontroler yang digunakan. Pada ATmega 328 pada Uno Arduino memiliki bootloader yang memungkinkan Anda untuk meng-upload program baru untuk itu tanpa menggunakan programmer hardware eksternal. Ini berkomunikasi menggunakan protokol dari bahasa C. Sistem dapat menggunakan perangkat lunak FLIP Atmel (Windows) atau programmer DFU (Mac OS X dan Linux) untuk memuat firmware baru. Atau Anda dapat menggunakan header ISP dengan programmer eksternal.

\section{Perangkat Lunak (Arduino IDE)}

Lingkungan open-source Arduino memudahkan untuk menulis kode dan meng-upload ke board Arduino. Ini berjalan pada Windows, Mac OS X, dan Linux. Berdasarkan Pengolahan, avr-gcc, dan perangkat lunak sumber terbuka lainnya. 
Jurnal Qua Teknika, Vol. 7 No. 2 September 2017

ISSN 2088 2424(cetak); 2527 3892(elektronik)

UNISBA Blitar, Http://qua.unisbablitar.ejournal.web.id

Imam Muklisin, Ahmad Sholehuddin, Muklison. 2017. Pendeteksi Volume Tandon Air Secara Otomatis Menggunakan Sensor Ultrasonic Berbasis Arduino Uno R3. Jurnal Qua Teknika, (2017), 7(2):55 65.

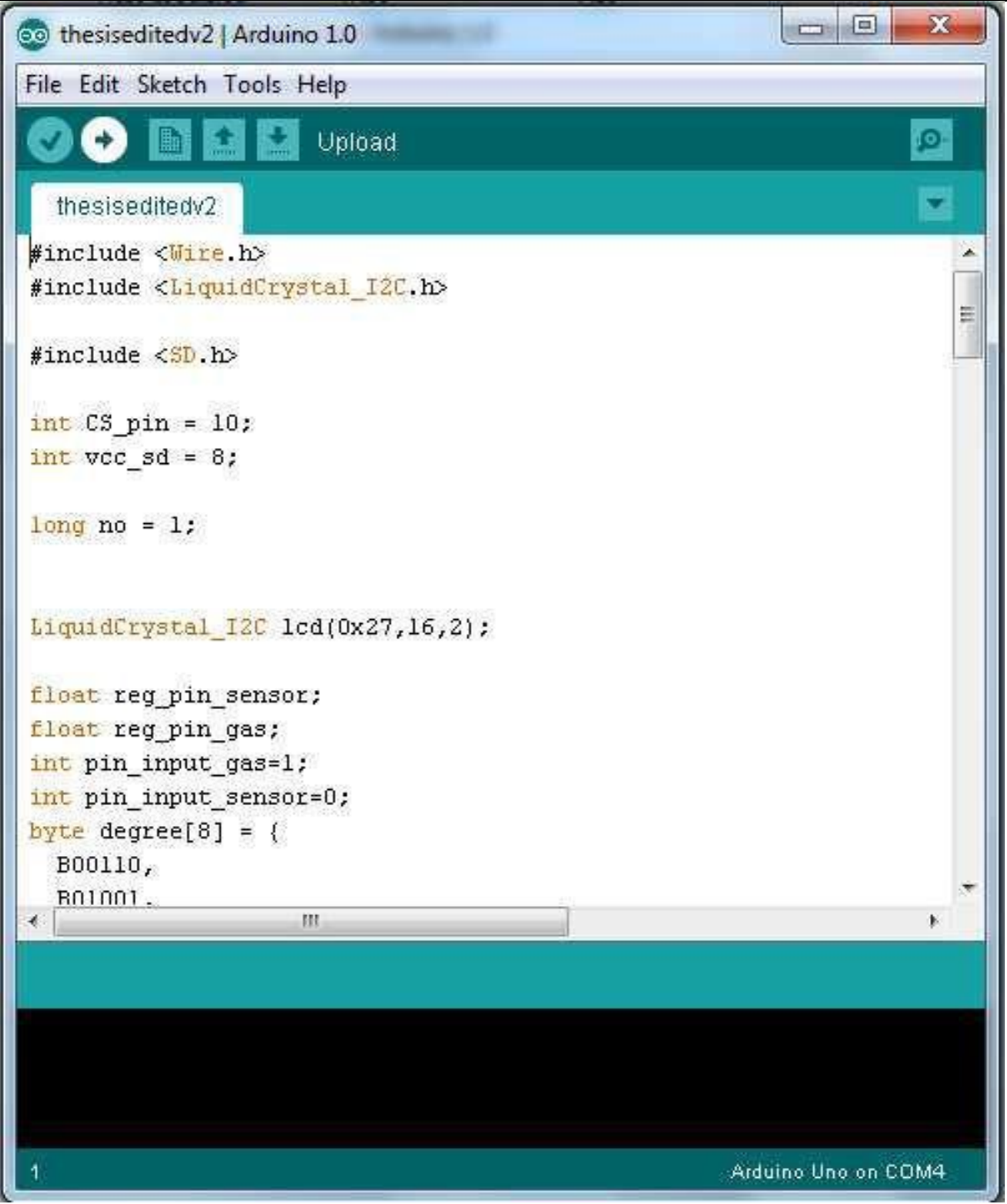

Gambar 2.3 Tampilan Framework Arduino UNO (Sumber : www.atmel.com)

\section{Otomatis Software Reset}

Tombol reset Uno Arduino dirancang untuk menjalankan program yang tersimpan didalam mikrokontroller dari awal. Tombol reset terhubung ke Atmega 328 melalui kapasitor 100nf. Setelah tombol reset ditekan cukup lama untuk me-reset chip, software IDE Arduino dapat juga berfungsi untuk meng-upload program dengan hanya menekan tombol upload di software IDE Arduino.

\section{ATMega 328P}

ATmega 328P adalah sebuah CMOS 8-bit mikrokontroler berbasis AVR dengan arsitektur RISC. AVR dapat mengeksekusi sebuah instruksi dengan 1 siklus clock, sehingga ATmega 328P dapat mencapai sekitar kecepatan eksekusi 1 MIPS (Microprosessor Whitout Iinterlocket Pipeline Stages) per Hz. Oleh karena itu ATmega 328P mengoptimisasi pemakaian daya VS kecepatan pemroses. 


\section{Relay}

Relay adalah komponen listrik yang bekerja berdasarkan prinsip induksi medan elektromagnetis. Jika sebuah penghantar dialiri oleh arus listrik, maka di sekitar penghantar tersebut timbul medan magnet. Medan magnet yang dihasilkan oleh arus listrik tersebut selanjutnya diinduksikan ke logam ferromagnetis.

Logam ferromagnetis adalah logam yang mudah terinduksi medan elektromagnetis. Ketika ada induksi magnet dari lilitan yang membelit logam, logam tersebut menjadi "magnet buatan" yang sifatnya sementara. Cara ini kerap digunakan untuk membuat magnet non permanen. Sifat kemagnetan pada logam ferromagnetis akan tetap ada selama pada kumparan yang melilitinya teraliri arus listrik. Sebaliknya, sifat kemagnetannya akan hilang jika suplai arus listrik ke lilitan diputuskan.

\section{LCD (Liquid Crystal Display)}

LCD (Liquid Crystal Display) adalah modul penampil yang banyak digunakan karena tampilannya menarik. LCD yang paling banyak digunakan saat ini ialah LCD M1632 Refurbish karena harganya cukup murah. LCD M1632 merupakan modul LCD dengan tampilan 2x16 (2 baris x 16 kolom) dengan konsumsi daya rendah. Modul tersebut dilengkapi dengan mikrokontroler yang didesain khusus untuk mengendalikan LCD.

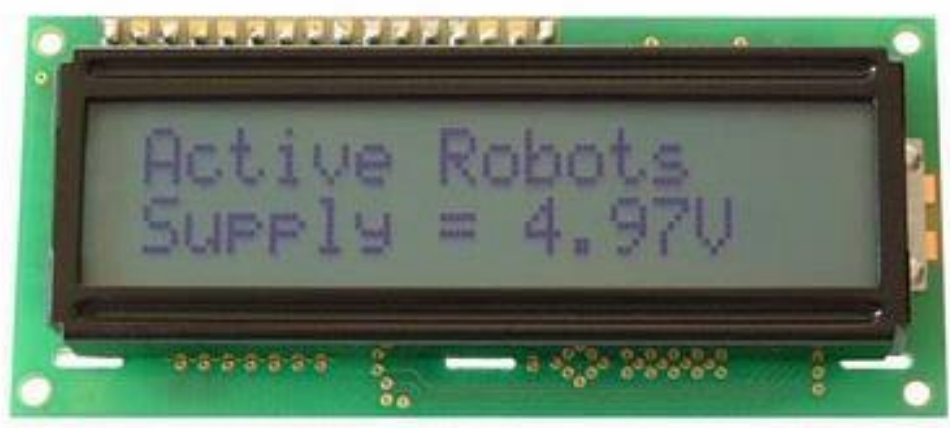

Gambar 2.8 Bentuk Fisik LCD 1632 (Sumber : www.leselektronika.com)

LCD ini digunakan untuk menampilkan nilai data dari sensor LM35, sensor gas MQ-6 dan informasi lain bisa ditampilkan di LCD ini. Banyak sekali kegunaan LCD dalam perancangan suatu sistem yang menggunakan mikrokontroler. LCD berfungsi menampilkan suatu nilai hasil sensor, menampilkan teks, atau menampilkan menu pada aplikasi mikrokontroler. LCD yang digunakan adalah jenis LCD M1632. LCD M1632 merupakan modul LCD dengan tampilan 16 × 2 baris dengan konsumsi daya rendah. Modul tersebut dilengkapi dengan mikrokontroler yang didesain khusus untuk mengendalikan LCD.

\section{Flowchart}

Flowcharting adalah suatu teknik untuk menyusun rencana program yang telah diperkenalkan dan telah dipergunakan oleh kalangan pemrogram komputer sebelum algoritma menjadi populer. Flowchart adalah untaian simbol gambar (chart) yang menunjukkan aliran (flow) dari proses terhadap data. Seorang pemrogram harus mampu membuat flowchart, harus mampu membaca dan mengerti flowchart, dan sanggup menerjemahkan flowchart ke algoritma dan sebaliknya.

\section{Sensor ultrasonic}

Sensor ultrasonic adalah sebuah sensor yang berfungsi untuk mengubah besaran fisis (bunyi) menjadi besaran listrik dan sebaliknya. Cara kerja sensor ini didasarkan pada prinsip 
dari pantulan suatu gelombang suara sehingga dapat dipakai untuk menafsirkan eksistensi (jarak) suatu benda dengan frekuensi tertentu. Disebut sebagai sensor ultrasonic karena sensor ini menggunakan gelombang ultrasonic (bunyi ultrasonic).

Gelombang ultrasonic adalah gelombang bunyi yang mempunyai frekuensi sangat tinggi yaitu $20.000 \mathrm{~Hz}$. Bunyi ultrasonic tidak dapat di dengar oleh telinga manusia. Bunyi ultrasonic dapat didengar oleh anjing, kucing, kelelawar, dan lumba-lumba. Bunyi ultrasonic bisa merambat melalui zat padat, cair dan gas. Reflektivitas bunyi ultrasonic di permukaan zat padat hampir sama dengan reflektivitas bunyi ultrasonic di permukaan zat cair. Akan tetapi, gelombang bunyi ultrasonic akan diserap oleh tekstil dan busa.

Pada sensor ultrasonic, gelombang ultrasonic dibangkitkan melalui sebuah alat yang disebut dengan piezoelektrik dengan frekuensi tertentu. Piezoelektrik ini akan menghasilkan gelombang ultrasonic (umumnya berfrekuensi 40kHz) ketika sebuah osilator diterapkan pada benda tersebut. Secara umum, alat ini akan menembakkan gelombang ultrasonic menuju suatu area atau suatu target. Setelah gelombang menyentuh permukaan target, maka target akan memantulkan kembali gelombang tersebut. Gelombang pantulan dari target akan ditangkap oleh sensor, kemudian sensor menghitung selisih antara waktu pengiriman gelombang dan waktu gelombang pantul diterima.

\section{Sensor Ultrasonic HC-SR04}

Sensor ini merupakan sensor ultrasonic siap pakai, satu alat yang berfungsi sebagai pengirim, penerima, dan pengontrol gelombang ultrasonic. Alat ini bisa digunakan untuk mengukur jarak benda dari $2 \mathrm{~cm}-4 \mathrm{~m}$ dengan akurasi $3 \mathrm{~mm}$. Alat ini memiliki 4 pin, pin Vcc, Gnd, Trigger, dan Echo. Pin Vcc untuk listrik positif dan Gnd untuk ground-nya. Pin Trigger untuk trigger keluarnya sinyal dari sensor dan pin Echo untuk menangkap sinyal pantul dari benda.

Cara menggunakan alat ini yaitu: ketika kita memberikan tegangan positif pada pin Trigger selama 10uS, maka sensor akan mengirimkan 8 step sinyal ultrasonic dengan frekuensi 40kHz. Selanjutnya, sinyal akan diterima pada pin Echo. Untuk mengukur jarak benda yang memantulkan sinyal tersebut, maka selisih waktu ketika mengirim dan menerima sinyal digunakan untuk menentukan jarak benda tersebut.

\section{METODE PENELITIAN}

Metode yang penulis gunakan untuk penelitian ini adalah metode eksperimen. Metode eksperimen yang penulis lakukan dalam penelitian ini adalah eksperimen yang dilakukan dalam laboratorium (laboratory experiment). Laboratorium tempat eksperimen dilakukan adalah laboratorium Teknik Elektro Universitas Islam Balitar Blitar.

\section{Variabel Penelitian}

Analisis yang digunakan dalam penelitian ini menggunakan dua variabel penelitian yaitu:

a) Variabel bebas (variabel independen): Variabel bebas penelitian ini adalah variasi Pompa Air Otomatis.

b) Variabel terikat (variabel dependen): Variabel terikat penelitian ini adalah hasil baca sistem Pendeteksi dan Pengontrol dengan Sensor Ultrasonic berbasis Arduino R3.

Alat dan bahan yang digunakan: a. Mikrokontroler (Arduino Uno R3), b. Sensor Ultrasonic, c. Relay, d. LCD, e. Pompa Akuarium, f. Kabel dan komponen-komponen pendukung lainnya.

\section{Implementasi dan Verifikasi}


Jurnal Qua Teknika, Vol. 7 No. 2 September 2017

ISSN 2088 2424(cetak); 2527 3892(elektronik)

UNISBA Blitar, Http://qua.unisbablitar.ejournal.web.id

Imam Muklisin, Ahmad Sholehuddin, Muklison. 2017. Pendeteksi Volume Tandon Air Secara Otomatis Menggunakan Sensor Ultrasonic Berbasis Arduino Uno R3. Jurnal Qua Teknika, (2017), 7(2):55 65.

Setelah sistem selesai dirancang, lalu pada tahap ini alat akan dirakit sehingga bisa untuk diuji atau disimulasikan untuk mengetahui hasil kerja dari alat ini.

Validasi

Setelah melewati tahap implementasi dan verifikasi maka tahap selanjutnya adalah validasi. Pada tahap ini dilakukan pengujian alat secara menyeluruh, meliputi pengujian fungsional dan ketahanan alat. Dari validasi ini dapat diketahui kesesuian hasil perancangan dengan analisis kebutuhan yang diharapkan.

\section{Finalisasi}

Pada tahapan ini adalah tahapan hasil dari alat yang sudah dirancang dan berjalan sesuai rencana.

\section{Rancangan Alat Pengendalian Pompa Air Otomatis}

Alat Pengendalian Pompa Air Otomatis merupakan sistem yang dirancang untuk mengatur pompa air kapan harus menyala dan mati sesuai dengan level bak penampungan air. Berikut akan diperjelas dari semua metode penyelesaian permasalahan yang terjadi pada Pengendalian Pompa Air Otomatis.

Adapun cara kerja rangkaian ini yaitu pada saat sensor Ultrasonic yang membaca data level air dalam bak penampungan air terbaca dalam keadaan kosong atau sensor low level aktif, maka pompa air secara otomatis akan ON dan mengisi bak penampungan air sampai terbaca high level (penuh). Sensor Low Level ini terhubung ke ATMega 328 pada PC.0 dan PC.1. Saat mikrokontroler mendapat logichigh, kemudian akan diproses pada sistem mikrokontroler. Setelah diproses oleh ATmega 328, kemudian mikrokontroler tersebut mengeluarkan output pada beberapa port. Output dari mikrokontroler ini dibagi menjadi dua, output pertama akan disalurkan ke Relay dengan port PA4 dan output kedua disalurkan ke tampilan LCD melalui port PC0-PC7.

\section{Blok Diagram Perancangan Sistem}

Rancang bangun penerapan Alat Pengendalian Pompa Air Otomatis dengan alurnya dapat dilihat dalam blok diagaram sebagai berikut:

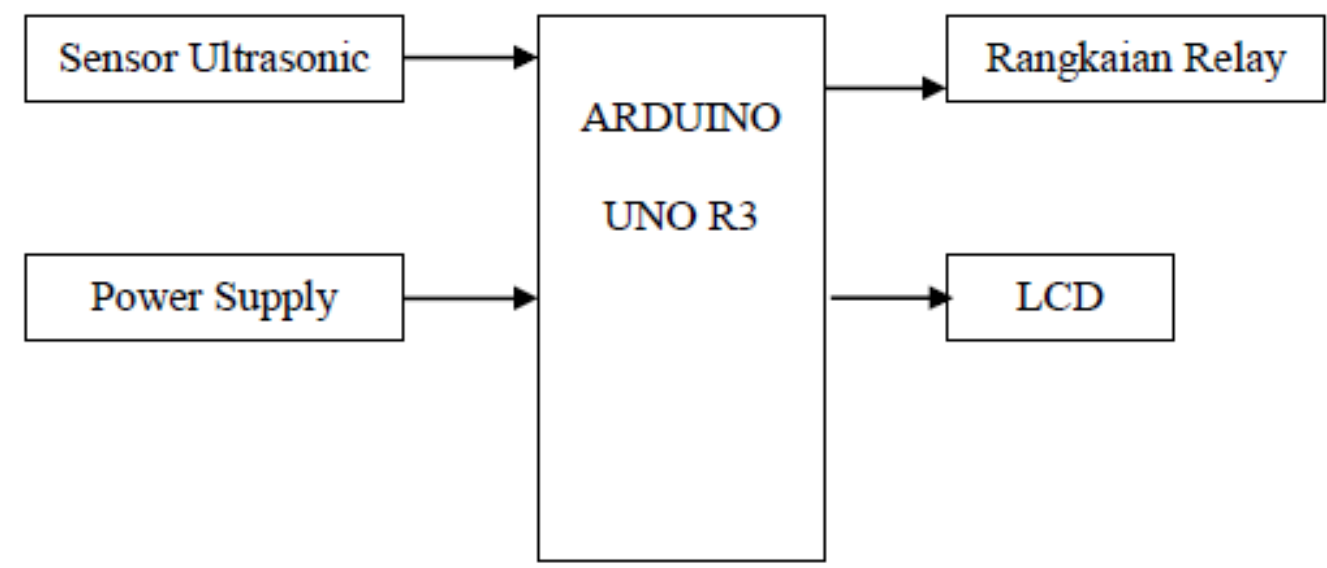

Gambar 3.1 Diagram Blok Alat Pengendalian Pompa Air Otomatis (Sumber : Dokumentasi Penulis)

Pada gambar blok diagram di atas dijelaskan bahwa awal proses kerja alat yaitu setelah mendapatkan tegangan input (power supply) alat langsung membaca data dari sensor Ultrasonic dengan data yang didapat dari Volume Tandon. Ketika sensor Ultrasonic membaca data yang ada pada tandon $0 \%$ maka berarti low level aktif dan ketika sensor Ultrasonic 
Jurnal Qua Teknika, Vol. 7 No. 2 September 2017

ISSN 2088 2424(cetak); 2527 3892(elektronik)

UNISBA Blitar, Http:// qua.unisbablitar.ejournal.web.id

Imam Muklisin, Ahmad Sholehuddin, Muklison. 2017. Pendeteksi Volume Tandon Air Secara Otomatis Menggunakan Sensor Ultrasonic Berbasis Arduino Uno R3. Jurnal Qua Teknika, (2017), 7(2):55 65.

membaca data yang ada pada tandon $100 \%$ maka berarti high level aktif. Jika sensor low level maka rangkaian relay high dan pompa menyala untuk menyalakan Pompa Air mengisi tendon air. Sedangkan sensor high level (100\%) maka rangkaian relay low dan pompa mati dengan sendirinya.

\section{HASIL DAN PEMBAHASAN \\ Pengujian Rangkaian Arduino Uno R3 dengan LCD}

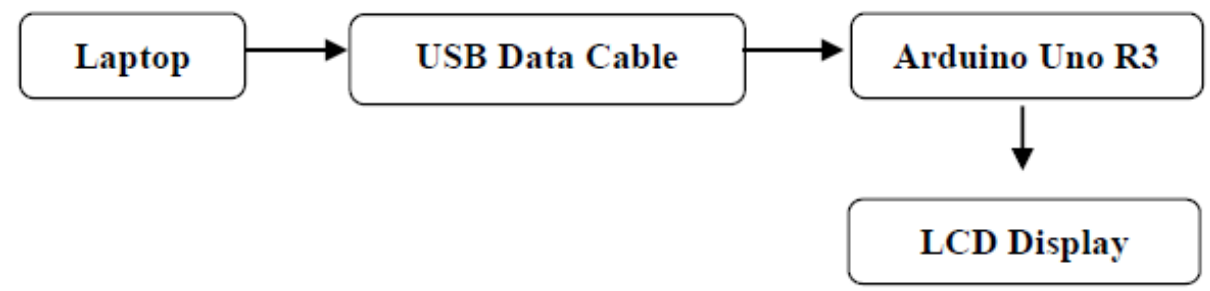

Gambar 1 Diagram Blok Pengujian Rangkaian Arduino Uno dan LCD

Pada uji coba rangkaian Arduino Uno R3 terhubung dengan LCD, diperlukan pemanggilan library “\#include $<$ LiquidCrystal $>$ ” yang berfungsi untuk menambahkan fungsifungsi program menampilkan karakter pada LCD.

Kemudian "LiquidCrystal lcd (8,9,4,5,6,7);" adalah listing program untuk pengaturan letak pin-pin kaki LCD dihubungkan ke pin-pin Arduino Uno R3. Penulisan pin-pin ini harus sesuai antara program dengan alat yang telah dipasang. Selanjutnya "lcd_begin(16,2);" yaitu pengaturan jumlah baris dan kolom sesuai LCD yang digunakan. Karena yang digunakan yaitu LCD 16x2 karakter, maka penulisan pada program ini yaitu "lcd_begin $(16,2)$;". Apabila menggunakan LCD yang berukuran $20 \times 4$, maka pada program seharusnya tertulis "lcd_begin (20,4);".

Untuk menuliskan "DISUSUN OLEH:" pada baris atas, dituliskan perintah "lcd.setCursor(0,0);" yang artinya penulisan karakter "DISUSUN OLEH:" dimulai dari kolom pertama dan baris pertama $(0,0)$. Angka 0 menyatakan dari awal kolom dan awal baris. Apabila menginginkan penulisan pada baris kedua, yaitu menggunakan perintah "lcd.setCursor(0,1); lcd.print("-IMAM MUKLISIN-");". Dan "delay(3000);" menyatakan penundaan waktu selama 3000 milisecond atau sama dengan 3 detik. Untuk menghapus tulisan pada layar LCD, diperlukan perintah "lcd_clear();". Secara keseluruhan hasil keluaran listing program yaitu menampilkan tulisan "DISUSUN OLEH:" pada baris pertama dan "-IMAM MUKLISIN-" pada baris kedua. Tulisan tersebut ditampilkan selama 3 detik (delay 3000) dan kemudian layar kosong (lcd.clear();) begitu seterusnya berulang-ulang karena listing program tersebut berada pada void loop ();:

\section{Pengujian Rangkaian Sensor Ultrasonic dengan LCD}

Pada pengujian rangkaian sensor level air, pada bagian awal hampir sama dengan pengujian sebelumnya. \#include <LiquidCrystal.h> $l c d(8,9,4,5,6,7)$; berfungsi untuk menambahkan library dan pengaturan LCD pada Arduino Uno R3. const int high_level = 6; const int low_level $=7$; menyatakan posisi sensor high_level pada pin 6 dan low_level pada pin 7 Arduino. Untuk menentukan nilai awal logic sensor diperlukan program int low_state $=0$; int high_state $=0$; yaitu dengan nilai awal “0”. Pin Mode(low_level, INPUT); pin Mode(high_level, INPUT); digunakan untuk mengatur mode pin sebagai input karena terhubung ke sensor. Sedangkan digital Write(low_level, HIGH); digital Write(high_level, HIGH); adalah untuk mengaktifkan internal PULLUP resistor pada Chip ATMega328 Arduino Uno R3. 


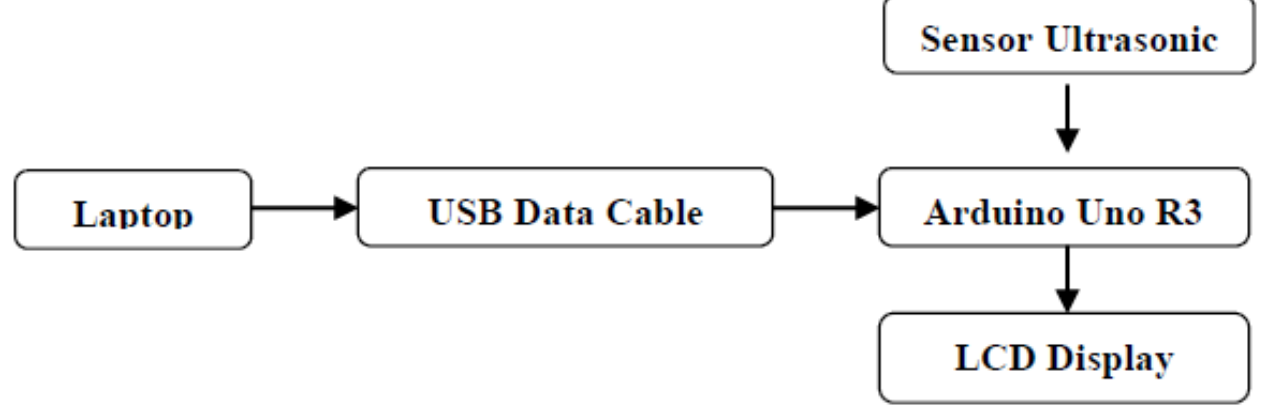

Gambar 2 Diagram blok rangkaian pengujian

Pada program utama, pada Void Loop, untuk membaca kondisi sensor level air secara real time, digunakan program low_state = digitalRead(low_level); high_state = digitalRead(high_level);

Setiap perubahan logika pada sensor akan ditampilkan pada layar LCD dengan menambahkan program lcd.setCursor(0, 0); lcd.print("L-lvl="); lcd.print(low_state); lcd.setCursor(9, 0); lcd.print("H-lvl="); lcd.print(high_state);

\section{Pengujian Rangkaian Relay}

Rangkaian relay ini merupakan saklar elektrik yang menerima sinyal output dari Arduino Uno R3. Rangkaian ini berfungsi sebagai saklar on/off pompa air yang digunakan pada simulasi alat. Pada pengujian ini dilakukan dengan memberikan program pada mikrokontroler untuk mematikan dan menghidupkan pompa air beberapa detik.

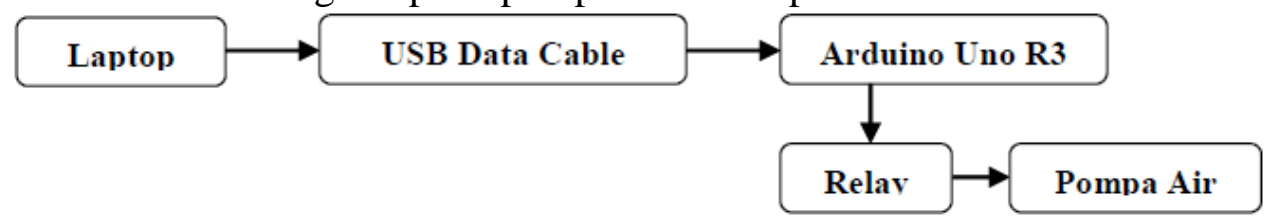

Gambar 3 Diagram Pengujian Rangkaian Relay dengan Output Pompa Air

Pada pengujian rangkaian Relay peralatan tambahan yang digunakan disini yaitu LCD yang berfungsi untuk menampilkan informasi bahwasanya Pompa Air dalam keadaan ON atau OFF. Pada pengujian ini, untuk mengaktifkan relay, diperlukan inisialisasi dan pengaturan pin yang digunakan untuk output relay. const int relay_pin $=8$; program ini digunakan untuk inisialisasi pin 8 sebagai relay_pin dan program pinMode(relay_pin, OUTPUT); berfungsi untuk mengatur relay_pin sebagai output.

Untuk mengaktifkan relay, dibutuhkan program digitalWrite(relay_pin, HIGH); yang artinya relay_pin diberi logika high "1". lcd.setCursor(0, 1); lcd.print("POMPA_AIR-ON"); delay(3000); sedangkan program ini untuk menampilkan informasi berupa tulisan pada LCD bahwa Pompa Air ON selama 3000 ms / 3 detik. Untuk menonaktifkan relay dan menuliskan informasi bahwa Pompa Air OFF menggunakan program digitalWrite(relay_pin, LOW); lcd.setCursor(0, 1); lcd.print("POMPA_AIR-OFF"); delay(3000);.

\section{Prinsip Kerja Akhir}

Prinsip kerja Alat secara keseluruhan merupakan gabungan dari serangkaian pengujian yang telah dilakukan. Pada saat pertama kali alat diaktifkan/dinyalakan, mikrokontroler melakukan inisialisasi input dan output dari sensor, relay dan LCD.

Setelah selesai inisialisasi, mikrokontroler Arduino Uno menampilkan tulisan pada LCD sebagai pertanda bahwa sistem sudah mulai bekerja yaitu menampilkan tulisan lcd.setCursor(0, 0); lcd.print(" DISUSUN OLEH: "); lcd.setCursor(0, 1); lcd.print("-IMAM 
MUKLISIN-"); delay(3000); lcd.clear();. Untuk melihat kondisi air pada tandon air, mikrokontroler membaca data sensor low_level yang artinya dalam kondisi $0 \%$ dan high_level dalam kondisi tandon penuh 100\%.. Apabila sensor -low_level=LOW dan high_level $=L O W$, itu artinya kondisi tandon air dalam keadaan kosong, sehingga mikrokontroler akan mengaktifkan relay, sehingga pompa air ON. Selama pompa air ON, mikrokontroler tetap membaca kondisi sensor apakah tandon air sudah penuh ataukah belum. Apabila sensor - low_level $=H I G H$ dan high_level $=H I G H$, berarti bak penampungan air sudah penuh, maka mikrokontroler dengan segera mematikan pompa air dengan merubah logika relay_pin $=L O W$;

Karena program ini berada di dalam void loop ()$\{\ldots . . .$.$\} maka program ini secara terus-$ menerus berulang-ulang membaca kondisi sensor. Apabila dalam keadaan kosong, maka pompa air akan aktif, dan ketika sudah penuh pompa air tidak aktif. Apabila kondisi sensor low_level $=H I G H$ dan $-h i g h \_l e v e l=L O W$, itu memiliki 2 arti, yaitu pompa air aktif dan sedang mengisi air, atau pompa air tidak aktif dan sedang menunggu akhir sampai habis.

Sedangkan pada saat kondisi 16\%, 33\%, 44\%, 50\%, 77\%, 94\%, 100\% Sistem hanya menampilkan persentase pada LCD tidak ada FEEDBACK ke Alat atau tidak ada umpan balik sama sekali.

\section{Kalibrasi Instrumen}

Kalibrasi merupakan kegiatan membandingkan hasil pengukuran sensor yang digunakan pada alat pendeteksi dengan alat standar ukur ketinggian yang biasa digunakan. Alat ukur ketinggian yang digunakan adalah Penggaris.

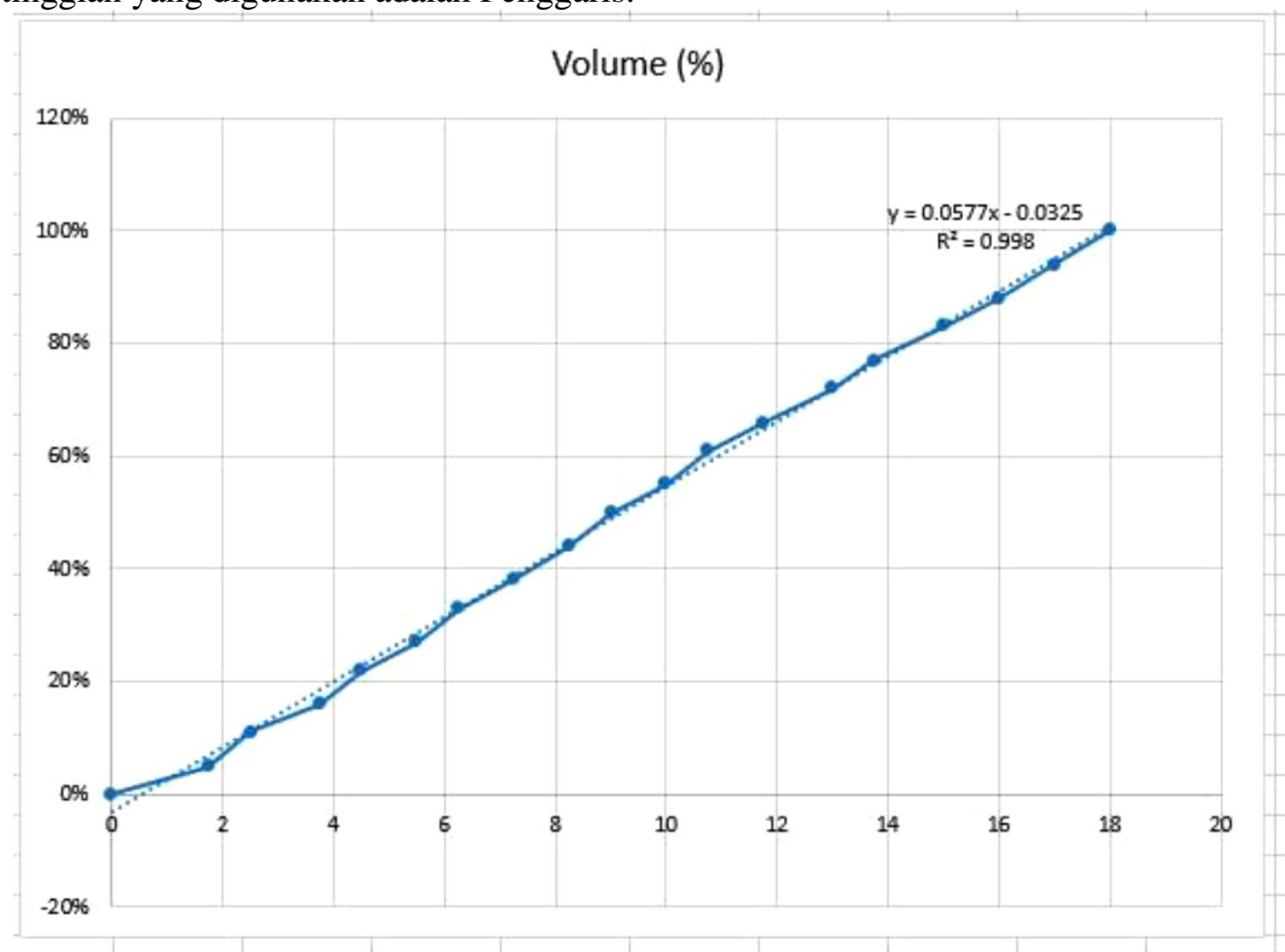

Gambar 4 Grafik eror pada kalibrasi alat

Komponen ukur tersebut diatas akan membandingkan hasil pengukuran sensor ultrasonik dan hasil pengukuran penggaris. Data hasil pengukuran menggunakan alat ukur standar akan dibandingkan dengan hasil pengukuran sensor ultrasonik yang yang tertera di LCD, sehingga 
Jurnal Qua Teknika, Vol. 7 No. 2 September 2017

ISSN 2088 2424(cetak); 2527 3892(elektronik)

UNISBA Blitar, Http:// qua.unisbablitar.ejournal.web.id

Imam Muklisin, Ahmad Sholehuddin, Muklison. 2017. Pendeteksi Volume Tandon Air Secara Otomatis

Menggunakan Sensor Ultrasonic Berbasis Arduino Uno R3. Jurnal Qua Teknika, (2017), 7(2):55 65.

didapatkan nilai keluaran yang tidak jauh berbeda antara hasil ukur menggunakan alat ukur yang berupa penggaris dan sensor ultrasonik yang tertera pada LCD. Hasil dari kalibrasi yang dilakukan ditunjukkan pada Gambar 4.

Dari Gambar 4 yang merupakan perbandingan antara jarak sebenarnya dengan jarak yang terukur pada sensor menunjukkan nilai yang tidak terlampau jauh dan masih mendekati angka sebenarnya. Jika dilihat dari Gambar 4 maka diperoleh data hasil pengukuran keakurasian jarak pada sensor ultrasonic yang digunakan. Nilai data kalibrasi diperoleh dari persamaan berikut:

$$
\mathrm{y}=0.0577 \mathrm{x}-0.0325, \mathrm{R}^{2}=0.998
$$

Berdasarkan nilai data kalibrasi tersebut maka akan diperoleh persamaan data error sensor ultrasonic menghasilkan error hingga $3.00 \%$ untuk kesalahan tertinggi dalam pengukuran $18 \mathrm{~cm}$. Rata-rata nilai kesalahan yang diperoleh $1.367 \%$.

\section{KESIMPULAN}

Setelah melakukan tahap perancangan dan pembuatan sistem yang kemudian dilanjutkan dengan tahap pengujian dan analisa maka dapat diambil kesimpulan sebagai berikut : 1). Sensor Ultrasonic dapat digunakan sebagai salah satu alternatif pendeteksi volume tandon air dengan menggabungkan beberapa komponen pendukung lainnya. Sensor Ultrasonic yang dipakai dalam pendeteksi memiliki keakurasian sangat tinggi dengan ketepatan 99,10\% dan kesalahan 0,90 \%. 2). Pada saat pertama kali alat diaktifkan/dinyalakan, mikrokontroler melakukan inisialisasi input dan output dari sensor, relay dan LCD. Jika tandon dalam keadaan kosong otomatis data yang terbaca sensor low dan diteruskan ke arduino yang akan menyalakan pompa. Begitu pula sebaliknya, jika tandon dalam keadaan penuh maka arduino akan otomatis mengirim data off ke relay.

\section{REFERENSI}

Abdul Kadir. 2013. "Panduan Praktis Mempelajari Aplikasi Mikrokontroler Dan Pemrograman Menggunakan Arduino”. Yogyakarta: Andi Publisher.

S. Wasito. 2001. "Vandemekum Elektronika”. Jakarta: Gramedia Pustaka Utama.

SELEX Communication. 2010. "Technical Handbook OTE DTR 100 VHF Transmitter".

Firenze: Aeronautical Radio Communication Solution.

Pujiono. 2012. "Rangkaian Elektronika Analog”. Yogyakarta: Graha Ilmu.

Zuhal.,dan Zhanggischan. 2004. "Prinsip Dasar Elektronika”. Jakarta: Gramedia Pustaka Utama.

Fatma, 2015. "Elektronika Dasar", (http://elektronikadasar.info).

Arduino, 2015. “Arduino Uno", (http://arduino.cc/en/Main/ArduinoBoardUno)

Chistianto Tjahyadi, 8 Januari 2015. "TransceiverRS232”. (http://christianto.tjahyadi.com) 